\title{
ADMINISTRATIVE MARKETING BARRIERS
}

\author{
FrANK BANE*
}

An examination of statutory barriers to market access, while affording an understanding of legislative determinations of general policy, leaves out of account the potentialities of administrative action for the creation of marketing barriers. These potentialities will frequently precipitate actual interference as the result of retaliatory action, the variance in regulations from state to state, lack of trained administrators, overzealousness in some instances, and occasionally political favoritism.

\section{INTERstate Trade Barriers}

In international parlance, the terms "indirect protectionism" and "administrative protectionism" are well understood. They have been defined as including "all measures of other than legislative origin, whether originating with ministerial, regulative, or administrative branches of governments which in their purpose, or in their effect, tend unreasonably to hamper the movement of international trade and to afford additional protection to producers, beyond the degree definitely prescribed or contemplated by the basic tariff regulations of the country." So in the national and municipal areas administrative action resulting from the grant of wide discretion to the enforcement officers and action extending beyond statutory authorization has perhaps been more often used for protecting local products and enterprises from out-of-state competition than has purposeful legislation. The ease and rapidity with which administrative action may be employed and the routine character of its application make trade barriers created under it difficult to discover and correct. Thus, state laws which provide for legitimate exercise of police powers may be so administered as to interfere with interstate commerce. This international analogy with its definition of administrative protectionism, when paraphrased to apply to the interstate situation, is, however, too limited and must necessarily be broadened to include instances of broad grants of discretionary powers where administrative action may be said technically to be contemplated by the basic statutory regulations of the state.

Administrative regulations which constitute barriers to the interstate movement of goods have thus far not received detailed attention from students of the trade barrier problem. Until this evidence is available, it will not be possible to assess

-A.B., I914, Randolph-Macon College. Executiva director, Council of State Governments. Lecturer on public welfare administration, University of Chicago; executive director, Social Security Board, 19351938. Contributor to periodicals. 
with certainty the proportion of trade barriers which have developed from the abuse of administrative discretion. The present discussion is based primarily on official complaints which have reached the Council of State Governments through the various state Commissions on Interstate Cooperation.

\section{Restrictions on the Entry of Goods Into the Market}

The milk industry has been a particularly fertile field for the establishment of trade barriers by administrative action and serves as an excellent example of the control that may be exercised through the device of inspection under color of a public health measure. Investigation by the Indiana Commission on Interstate Cooperation shows that in many instances the restrictions by the East upon the importation of Midwestern dairy products have been through administration of the regulations rather than by following the letter of their texts. The usual situation might be described as one in which an Eastern community will permit the importation of any dairy products which meet its sanitary requirements; however, it alone must be the judge of the purity of such imported products; it, the community, has a more competent, more highly trained, more skillful corps of inspectors than any other unit of government-inspectors who, alone, know what products will meet the health requirements of the community; however, they regret that it is physically and financially impossible for their corps of inspectors to make a complete tour of inspection of farms and herds in Illinois, Indiana, Kentucky, Michigan, Minnesota, Ohio, Tennessee, Wisconsin; and therefore, of necessity, their inspection, like charity, must begin at home. Of pertinent interest is the further evidence collected by the Indiana Commission that inspections beyond the confines of a limited area are made only in times when there is a shortage of the local supply.

Other authorities, suggesting that Indiana might first put its own milk house in order, offer in rebuttal evidence showing that Indiana cities discriminate in the same way against milk shipped in from other milk sheds within the state but not immediately adjacent to the city.

Aside from the fact that recognition is not extended to the validity of inspection certificates issued by the producing states, the entry of goods into the market is similarly affected by diverse regulations with respect to labeling requirements. A regulation adopted by the Dairy and Food Commission of Connecticut requires cartons containing butter to which color has been added to bear as part of the label, the words "artificially colored." Connecticut is the only state having such a requirement and butter is specifically exempted by the Federal Government from food required to be so labeled. Owing to the fluctuating natural color in butter, it has been considered good practice in the industry to maintain a fairly constant color during all seasons of the year. It is significant to note that the Connecticut regulation does not prohibit the use of coloring, nor does it specify any types of coloring which it considers injurious to public health. The regulation becomes a trade barrier in that butter producers have no knowledge of the ultimate destination of butter 
manufactured and shipped in large lots. If the industry does not withdraw entirely from the Connecticut market, it is faced with a choice between the expense of segregating shipments destined for that state and labeling cartons in those shipments differently from those used in all other markets, and labeling butter for all markets in such a way as to make it eligible for sale in Connecticut, a step which would put it at a distinct disadvantage for sale in any other market.

The action of Congress in adopting certain provisions of the Agricultural Adjustment Act of 1938 with subsequent amendments, has given rise to additional administrative barriers to the free flow of dairy products from Midwestern to Eastern markets. Without regard to questions of public policy and solely for the avowed purpose of stabilizing the marketing of dairy products in the metropolitan areas of the East, geographic limitations have been arbitrarily placed around production and marketing areas within which prices of dairy products are fixed by public authority. Orders promulgated under authority of this Act of Congress have threatened to put an end to the remaining exportation of cream and milk products from the Midwestern states to the Eastern markets.

Plant quarantine regulations have been administered in many instances in such a way that administrators have been accused of using their powers purely for the sake of erecting barriers. A Special Report of the Bureau of Agricultural Economics in March, 1939, quotes a criticism of the administration of the alfalfa weevil quarantine which is typical of this area of administration: ${ }^{1}$

It appears that they use this quarantine, which they put on or take off apparently at will, to protect their hay growers in times of low prices or to open a market for the stockmen in times of high prices. That is, if they need (our) native hay or alfalfa in an area of (their State) which cannot be supplied by it, they relax the quarantine measure. If they have plenty of hay, the quarantine is maintained.

These instances of quarantine manipulation and of the artificial methods of maintaining prices affecting the entry of goods into the market indicate the latitude of discretion given to administrative officers. This same latitude with its possibilities of indirect favoritism may be found in the application of the inspection and port of entry laws and other similar ostensible health and police measures.

\section{Restrictions on the Entry of Persons Into the Market}

The entry of persons into the market, because of the difficulties of fixing legislative standards of personal qualifications, is to a great extent left in the hands of administrators. Here the administrative discretion is like the Chancellor's conscience which is measured by the length of the Chancellor's foot. The finality of such administrative action is well expressed by the General Counsel of the Securities and Exchange Commission:2

1 Taylor, Burtis and Waugh, Barriers to Internal Trade in Farm Products (U. S. Dep't Agric., 1939) 93.

${ }^{2}$ Lane, Symposium on Administrative Law (1939) 9 AM. L. Schoor Rev. 139, at 162. 
Candor compels me to admit, however, that the remedy of judicial review, in most cases, has no practical content. Business transactions cannot wait upon the exigencies of appeal. The overwhelming mass of administrative determinations are never reviewed by the courts. Time is of the essence. Even appellate procedure within the administrative body by no means insures that the unfortunate results of action unwise or arbitrary will be cured. The remedy of appeal is not adequate.

The state, in the exercise of its police power, is authorized to subject all occupations to a reasonable regulation where such regulation is required for the protection of public interests or for the public welfare. Pursuant to this principle, laws have been enacted requiring a license or certificate to practice a profession and many other laws have been passed in which the right to engage in a calling or occupation other than a learned profession, is conditioned upon the securing of a license. Illustrations of laws affecting such occupations are: steam engineers, inspection of steam boilers, barbering, nursing, pharmacy, funeral directing and embalming, aircraft piloting, real estate brokerage, and so on. While these provisions affecting entry of persons into occupations apply to persons within the state as well as those out of the state, additional requirements such as residence for a prescribed period are in many cases imposed. This favoritism of the "native" as a declaration of legislative policy, together with the perhaps natural inclination to protect the "home town boys," often results in a strained construction of the provisions with respect to qualifications.

In the case of itinerant truckers, most states do not require a farmer living in an adjoining state to obtain license plates for his truck if he merely uses the truck for the purposes of marketing items produced on his own farm. Administrators have the power, however, in granting the exemption to determine whether the products are in fact produced by the farmer. In many states each case is handled on its merits with no fixed rule regarding the type of proof required. Proofs submitted by farmers in such cases take the form of official grower's certificates, official tax receipts on the land farmed, and registration papers carrying a rural address. Regardless of the type of proof, the administrator may in his discretion refuse to grant the exemption.

Many states have purchase preference statutes requiring that non-resident firms, in order to be eligible for a contract, bid more than three percent beneath the lowest local bid. This statutory trade barrier plus administrative action in refusing to furnish bidder's lists has resulted in discrimination beyond the expressed intent of the legislatures. In the Council of State Governments' drive to eliminate purchase preference laws as a form of trade barrier, information has been forthcoming from some states to the effect that they would be entirely willing to repeal this obvious barrier because the administrative purchasing agent would surely favor his own state.

However, broad as is the latitude granted the administrator and frequent as the instances have been of discrimination against out-of-state products and persons 
by administrative action, nevertheless it seems a safe generalization to say that, as a group, experienced administrators are less prone to impose barriers than are those legislators who, in an effort to please local business interests or their constituents, have in the past sought to obtain a legislative declaration of policy in this direction. Fortunately, administrators of the other view are in the minority and are rapidly losing whatever influence they once had.

The motor vehicle administrators have made progress, frequently wiping out state barriers to the full extent that their administrative authority will allow them to do so. In their willingness to destroy barriers they have used silence in the statutes to issue rules and regulations in conformity with the practice of their neighbors. In some cases they have run ahead of legislative intent. For instance, one state four years ago passed a resolution forbidding the motor vehicle administrator from adopting reciprocal regulations. The administrator disregarded the resolution and within a month was forced by statute to refuse any and all reciprocal agreements with neighboring states.

\section{Non-Grographtcal Marketing Barrters}

Marketing barriers are also raised by administrative rulings of a different character. Favoritism of administrators for particular products or methods of doing business apply as well within the state concerned rather than being erected on the state line. This is the most difficult type of barrier to discover and resolves itself into general questions of economic policy. In the administrative field it is, of course, only an expression of a similar economic favoritism established by legislative policy resulting from pressures of economic competitors. The extent of the practice of this type of favoritism by administrators is doubtless widespread. However, there are no means of actually gauging the development, and the citation of sporadic instances is about as far as it is possible to look into the problem at the present time.

State purchasing agents, for instance, are at complete liberty to choose between identical bids which may be submitted by independent retailers, mail-order houses, or chain stores. The extent to which impartiality is shown will depend entirely upon the individual purchasing agent and his resistance to specific pressures which may be brought to bear upon him.

Frequently departmental rulings without statutory basis go unnoticed and unchallenged excepting by the group injured. The Department of Agriculture in one of our Midwestern states recently issued a ruling requiring the use of paint with a soybean oil base on all public buildings in the state. This regulation inevitably called forth an immediate protest from the well-organized industry adversely affected, and the ruling was subsequently revoked. On the other hand, the paint situation typifies the predicament in which new products are likely to find themselves as the result of administrative regulations written at an earlier period of time. Undoubtedly the rulings of numerous states specify that paint on public contracts must contain white lead and linseed oil. Such rulings were probably not inspired by a 
desire to advantage linseed oil manufacturers but by the common, and correct, belief that linseed oil was then the best paint oil. But regulations of this character now operate to the disadvantage of the soybean interests, since for many purposes soybean oil is fully equal to linseed in paints. Distributors of prefabricated houses find themselves in a like situation as a result of the fact that most building codes, drafted in the prefabrication era, are not favorable to the construction principles applied in building the made-to-order house. Judging from investigations undertaken by the Department of Justice, there is basis for believing that a hostile administrative attitude often works against the new type of construction where discretion is left to the inspector.

Stringent sanitary regulations governing the manufacture of ice cream by the use of "counter freezers" provide a basis for administrative discouragement or prohibition of the integration of the businesses of manufacturing and selling this product. Here, however, the action taken is largely dictated by the basic legislative provisions the regulatory body is enjoined to enforce. But exercise of administrative discretion not demanded or perhaps even contemplated is to be found in the action of an Eastern milk board in requiring milk dealers selling milk in paper containers to charge one cent more than those selling in bottles. Naturally, such action does not go unchallenged.

Difficult as it is to pin down trade barriers erected by administrative action, and impossible as it is at this time to make a comprehensive list of such walls to the free movement of goods and services, the problem is nothing in comparison with that of tracing these barriers through the semi-administrative, administrative-judicial, and fields controlled by private or semi-public groups. For instance, administrativejudicial interpretation of the Sherman Act has restrained meat packers from selling groceries, while the rival demands of various union labor groups in different parts of the country have made it impossible in some instances for manufacturing companies to fulfill orders. A Detroit manufacturing company has found that in certain Northwestern states electricians will not install lighting fixtures unless they bear A. F. of L. labels, whereas in certain Midwestern states a CIO label is required. Obviously, the manufacturing company cannot satisfy both demands.

This brief appraisal of administrative action creating trade barriers is hardly an approach to the problem. The possibility of abuse necessarily permeates all statutes, for discretion must be granted to permit the proper functioning of government. The answer does not lie in legislative limitation, but in the direction of closer association of administrative officials engaged in the same work from state to state. Herein doubtless lies the success which motor vehicle administrators have had, as well as the notable advances being made in the matter of plant quarantines by the several regional plant boards that are composed of the agricultural administrators of all of the states. 